\title{
A Study on the Policy of Driving Xi'an 's Innovation and Entrepreneurship through Equity-based crowd-funding

\author{
${ }^{1}$ Jing Ren
}

1Shaan xi Institute of International Tread\& Commerce, Xi'an, China

Keywords : Equity-based crowd-funding, Innovation and Entrepreneurship, drive

\begin{abstract}
The rise of the Equity-based crowd-funding to raise equity to solve the mass innovation, the entrepreneurial start-ups financing, financial resources, financial pattern of the problem. How to regulate the development of public equity chips, effectively boost innovation and entrepreneurship to achieve leapfrog development, become a priority. Based on the analysis of the public to raise equity and innovation based on the fit, through empirical analysis, seeking to raise public equity factor positive driving Xi'an innovation and entrepreneurship development, explore the sustainable development of Xi'an to raise public equity driven innovation enterprise policy and path selection.
\end{abstract}

\section{股权众筹驱动西安创新创业发展政策研究}

\section{任静}

陕西国际商贸学院, 西安, 中国

关键词：股权众筹 创新创业 驱动发展

摘要：股权众筹的兴起解决了 “大众创新、万众创业” 初创企业融资金、融资源、融格局的 问题。如何规范股权众筹发展, 有效助推创新创业实现跨越式大发展, 成为当务之急。本文 在分析股权众筹与创新创业契合度的基础上，通过实证分析，寻求股权众筹正向驱动西安创 新创业发展的影响因子，探索股权众筹驱动西安创新创业企业可持续发展的政策选择和路径。

\section{一、股权型众筹及其与创新创业的契合度考察}

股权众筹, 指募资人即处于创业初期的项目创意人或有融资需求的小微企业在互联网股 权众筹平台上发布其创业信息、项目信息并做出出让股份份额的承诺等来吸引广大投资者的 兴趣，待项目成功后，项目投资人获取一定份额的公司股份作为回报的互联网融资模式。[1]

股权众筹通过互联网形式进行公开小额股权融资的活动， [2]能以更灵活的方式为小微 企业和创业者提供融资服务，可满足中产阶级的投资需求，被为是 “双创”的 “孪生姐妹”。 截至 2015 年底, 全国股权众筹平台累计成功众筹项目数达 2338 个, 累计成功众筹金额近 百亿元人民币。平台上线的项目创业创新特点明显, 集中分布在移动互联与社交网络、消费 生活、智能硬件、娱乐传媒与生活服务等新兴行业领域, 反映出股权众筹在支持创业创新中 的重要作用。以国内领先的精品股权投资项目互联网服务平台 “京北金融” 为例, 该平台致 力于互联网金融类初创企业融资, 在创新创业企业、项目孵化中功不可没。股权众筹与创新 创业在特点、本质上具有高度契合性, 互动转化成为可能。 


\section{二、股权众筹助推西安地区创新创业企业发展现状调查}

\section{1、股权众筹在西安的发展现状}

股权众筹助推西安地区创新创业企业发展主要有三种形式: (1) 全国性众筹平台为西 安地区创新创业企业提供上线融资。众筹家调查显示，人人投、众投帮、京东东家、360 淘 金、大伙投、36Ke 等国内一线私募股权众筹平台纷纷布局国内外市场，各家通过孵化器、天 使茶馆、商学院等形式吸收和对接优质创业融资项目。（2）全国性股权众筹平台在西安设 立分支机构。以人人投为例, 截至 2016 年 8 月, 人人投在西安地区众筹项目 17 项, 涉及领 域涵盖医药、酒店、餐饮、快消品等行业, 极大程度解决西安地区实体店铺创业形式的融资 问题。（3）西安本土股权众筹平台服务西安本土创新创业企业发展。由于创新创业与互联 网金融的天然 “互生互长” 关系, 西安高校纷纷开始高度重视 “双创” 工作, 科研院所的创 新热情日渐高涨, 创业融资需求迫切, 在此背景下, 催生出 “陕众筹”、“创业中国-股权 众筹平台” 等本土股权众筹平台。这两家众筹平台致力于不同的股权众筹细分领域。

\section{2、创业中国-股权众筹平台案例介绍}

（1）创业中国股权众筹平台概况

创业中国股权众筹平台于 2014 年 7 月 9 日上线运营，由陕西科技创业投资管理有限公 司负责具体运营管理。创业中国股权众筹平台是西部首家股权众筹融资平台，以创投的流程 做众筹。

从众筹运营模式分类看，创业中国股权众筹业务模式是将 “无领投股权众筹业务模式” 和“领投+跟投”业务模式的相结合而形成的业务模式。(1)融资者提出申请(2)项目审核及发布。 (3)确定是否有领投人。创业中国股权众筹平台的领投人是投资人申请确定，获取领投资格的 投资人需要具备某一方面的行业背景或社会资源、在创业中国至少跟投过一个项目等条件。 如项目并无人申请领投, 则直接进入下一融资环节。(4)项目筹资。设定的期限内如果没有完 成目标融资额, 则该融资项目宣布失败; 如融资项目成功则进入项目运行阶段。(5)项目完成。

以完成的股权众筹项目为例， 2015 年 9 月 8 日西安奇妙电子科技有限公司向创业中国 提交了名为 “ohh 智能家居” 的融资项目, 设定的目标融资额为 500 万。设定认购期限为 10 天，并提交了商业计划书和相关项目融资信息。这一项目经平台审核后发布，在募资期内有 1 人申请作为领投人, 4 人参与跟投并按期完成目标融资额。投融资双方通过签立合伙协议, 确定了各方的权利和义务。

（3）创业中国上线项目

创业中国股权众筹平台上线一年来, 开展项目融资 13 项, 额度达 2730 万元, 对接的科 技企业涵盖智能家居、航空航天、电子信息、互联网、智能硬件等领域。如表 3.1 所示:

\begin{tabular}{lclc}
\hline 项目名称 & 融资额度 & 行业类别 & 领投数 \\
\hline Ohh 智能家居 & 500 万 & 智能家居 & 1 \\
军用无人机 & 550 万 & 航空航天 & 1 \\
“综治通” 视频监控管理平台 & 200 万 & 电子信息 & 1 \\
恋爱三部曲 020 平台 & 100 万 & 互联网 & 1 \\
护眼功能饮品 & 200 万 & 生物医药 & 3 \\
小 $V$ 智能云端故事机 & 150 万 & 智能硬件 & 0 \\
360 度旋转拍摄摄像机 & 120 万 & 电子硬件 & 0 \\
\hline
\end{tabular}

表 3.1： 创业中国股权众筹平台项目数据

\section{3、陕众筹项目案例分析}

（1）陕众筹运营模式

陕众筹是一个集产品众筹、股权众筹、捐赠式众筹为一体的综合性众筹平台。为创业起 步、融资困难等中小型发展型企业提供项目品牌推广，全方位金融财税服务，营销等服务。 自成立以来，共撮合融资项目 259 个，在线项目 280 个, 认筹金额达 24822051.02 元，在陕 
西互联网金融行业颇具影响力。

陕众筹运营模式属于无领投股权众筹业务流程，但同时又吸收了 “领投+跟投” 的优势。

（2）陕众筹上线项目

(1)雅健烘焙 2015 年 6 月在陕众筹上线融资，融资情况如表 3.2 所示:

\begin{tabular}{ccccccc}
\hline 项目 & 融资金额 & 出让股份 & 起投金额 & 跟投人数 & 融资比例 & 融资时间 \\
\hline 雅健烘培 & 148 (万元 $)$ & $49.3 \%$ & 1 (万元 $)$ & 22 & $100 \%$ & 2015.6 \\
\hline
\end{tabular}

表 3.2: 陕众筹股权众筹项目一雅健烘焙融资数据

(2) 易捷快送-基于互联网的本地生活物流。2015 年 6 月易捷快送一一基于互联网的本地 生活物流项目在陕众筹上线融资，融资情况如表 3.3 所示:

\begin{tabular}{lrrrrrr}
\hline 项目 & 融资金额 & 出让股份 & 起投金额 & 跟投人数 & 融资比例 & 融资时间 \\
\hline 易捷快送 & 200 (万元 $)$ & $20 \%$ & 5 (万元 $)$ & 2 & $100 \%$ & 2015.6
\end{tabular}

表 3. 3: 陕众筹股权众筹项目一一易捷快送融资数据

(3)广誉远康成君健国药堂。2015 年 4 月康成君健国药堂项目在陕众筹上线, 融资情况 如表 3.4 所示:

\begin{tabular}{lcccccc}
\hline & 融资金额 & 出让股份 & 起投金额 & $\begin{array}{c}\text { 跟投人数 } \\
\text { 融资比例 }\end{array}$ & 融资时间 \\
\hline 广誉远康成君健 & 100 (万元） & $70 \%$ & 10 (万元) & 52 & $103 \%$ & 2015.4 \\
\hline
\end{tabular}

表 3.4: 陕众筹股权众筹项目一一广誉远康成君健国药堂融资数据

除了陕众筹和创业中国这两个本土股权众筹平台外, 能为企业提供股权融资的还有陕西 省股权交易服务托管中心，陕西股权交易服务托管中心的主要满足小中型企业融资需求。

\section{三、股权众筹驱动西安地区创新创业企业发展分析}

\section{1、股权众筹驱动西安地区创业企业发展的瓶颈}

（1）股权众筹规模与创业融资企业总量发展不平衡

西安地区股权众筹规模与创业融资企业总量发展不平衡表现在两个方面: 一是即使面对 具有包容性、开放性的全国一流股权众筹平台, 西安创业企业上线融资也容胗无几。另一方 面陕西股权众筹平台数量少, 截至 2016 年 8 月, 陕西众筹平台仅 2 家, 且影响力也小。平 台具体数量地域分布情况如图 4-1 所示 [3]:

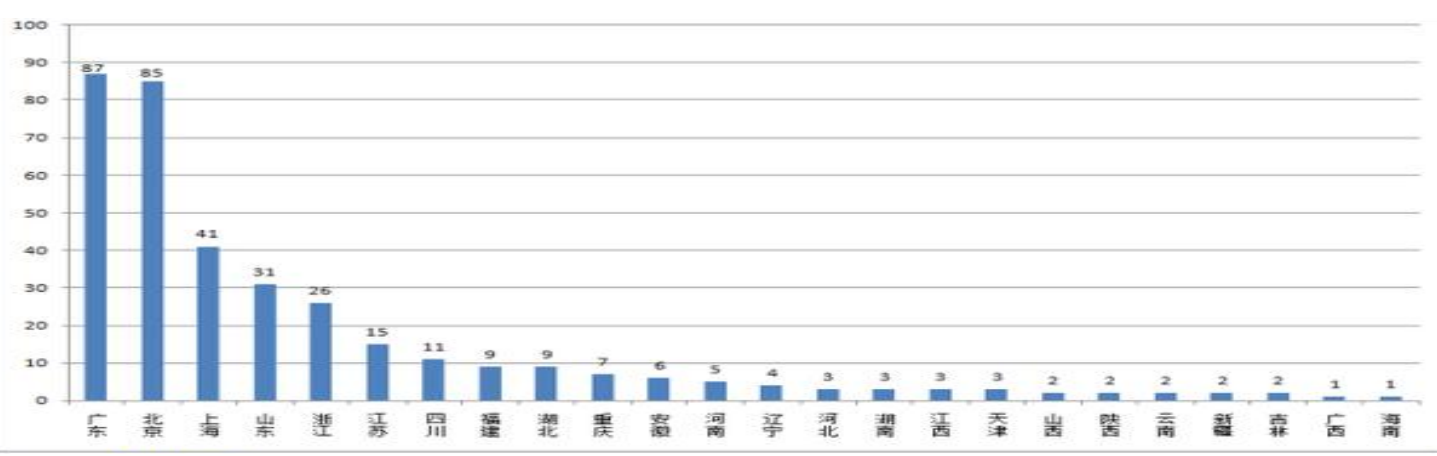

图 4-1 360 家众筹平台分布（不含港澳台） 
（2）西安地区股权众筹平台运营能力欠缺、运营模式不健全

统计显示, 西安地区股权众筹平台发展滞后, 运营能力亟待提高, 西安地区股权众筹平 台运营体现出两个特点:一是项目对接数量较少, 服务地方创新创业企业能力不足。资源整 合能力贵乏。甚至有的平台成立近 2 年, 服务地方创新创业数不足 10 个。二是运营效果不 佳, 对接项目众筹失败率高, 以创业中国为例, 众筹失败率高达 $67 \%$ 。西安地区部分股权众 筹平台运营数据如表 4-1 所示:

\begin{tabular}{cccc}
\hline 平台名称 & 上线项目数 & 西安本土企业上线数 & 众筹失败率 \\
\hline 陕众筹 & 259 & 118 & $16.9 \%$ \\
创业中国 & 14 & 12 & $67 \%$ \\
诚为众筹 & 26 & 3 & $50 \%$ \\
& 表 $4-1$ & 部分西安股权众筹平台运营数据 & \\
\hline
\end{tabular}

导致众筹失败因素很多，从宏观的股权众筹架构主体角度分析，一方面项目融资方可能 存在对股权众筹融资认识不足、股权众筹设计存在问题等。另一方面可能存在投资人项目识 别能力、投资水平、资源整合等问题。第三, 平台方存在运营不力、不专业、组织管理机制 不顺、制度设计不科学不合理等。

（3）股权众筹驱动西安创新创业企业发展效果不显著

从对陕众筹和创业中国股权众筹平台调研数据看，陕西股权众筹平台服务领域较窄，所 属细分领域的平台专业性不强, 缺乏这一领域的领投人及相应资源, 在项目运作中漏洞较多, 服务创新创业企业能力较为薄弱, 从表 4-2 可窥见一斑:

\begin{tabular}{ccc}
\hline 股权众筹平台 & 所属细分领域 & 服务领域 \\
陕众筹 & 综合平台 & 涵盖医疗、科技、农业等 \\
\hline 创业中国 & 股权众筹 & 科技企业 \\
诚为众筹 & 股权众筹 & 餐饮、科技等 \\
\hline
\end{tabular}

\section{2、驱动效果影响因子分析}

（1）政策监管。政策监管在很大程度上影响着众筹平台的生存与发展，2015 年 12 月 28 号《网络借贷信息中介机构业务活动管理暂行办法 (征求意见稿)》出台, 致使大批从事股 权众筹的 P2P 平台停业或转型。如西安 P2P 兼众筹平台 “钱趣网” , 就因监管政策的出台导 致汽车众筹、房产众筹业务的失败。

（2）众筹平台模式设计。就西安几家众筹平台而言，几乎全部存在平台设计问题，包括 平台交互、项目甄别、遴选到投资设计等。研究表明: 是否有领投人与融资是否成功存在密 切关系。有领投人的融资项目更容易获得融资成功 $[4]$ 。如表 4-3 所示。此外，投后管理、 退出机制、“领投+跟投” 业务模式都是平台运营模式的一部分, 每一步的设计都成为影响 股权众筹能否驱动创新创业企业发展的效果。

\begin{tabular}{|l|l|l|}
\hline 是否有领投人 & 融资失败 & 融资成功 \\
\hline 无领投人 & 88 & 1 \\
\hline 有领投人 & 0 & 15 \\
\hline
\end{tabular}

\section{表 4-3 是否有领投人与融资是否成功的关系}

（3）法律防范。目前影响股权众筹运用的最大风险是法律风险。这其中包括非法吸收公 众存款的风险、非法发行证券的风险、集资诈骗的风险。此外, 我国股权众筹融资存在法律 防范的制度缺陷, 主要表现在: 一是风险防范法律监管主体冗杂而无序。二是单薄僵硬的股 权众筹融资主体风险防范法律监管规则; 三是后置性风险防范法律监管措施的缺失 [5]。

（4）融资方与投资方能力及素质。股权众筹从本质来讲是金融范畴，专业的金融知识和 防风险素质是影响投融资成败的关键因素之一。创业者对资本市场的认知以及相关规则设计、 
交互设计等方面需要加强学习。而作为投资人则应该具备一定风险意识及相关专业知识。

\section{四、股权众筹正向驱动创新创业企业可持续发展政策建议}

\section{1、加快立法进程, 明确监管措}

2015 年被称为股权众筹元年。股权众筹在我国处于快速发展时期，平台数量逐年激增, 野蛮生长、恶性竞争的局面己经出现。必须尽快出台完备的《股权众筹指导意见》来监管股 权众筹。内容应包含以下几点: 第一, 确立股权众筹合适的法律地位。让股权众筹有法可依、 有章可循, 进入良性发展、规范发展的轨道中去。第二, 规范股权众筹平台的运行制度。第 三, 明确平台的权利与义务, 做好筹资方、投资方的资格审核、融资项目的尽职调查, 制定 合理的盈利模式。最后，完善融资者信息披露机制。

\section{2、从制度设计层面防范法律风险}

众筹融资风险防范法律制度设计应从以下几方面着手：首先制定全面的众筹融资主体 风险防范法律监管规则。筹资方：设计科学的信用评估制度和有效的信用评估执行; 完善失 信惩罚机制与损失赔偿机制；投资方：制定出台《众筹融资投资方适当性管理细则》；明确 投资方分层管理原则; 加强投资教育, 保护知识产权; 众筹平台: 建立健全市场准入与退出 机制; 构建成熟完整的流程管理模式; 设置适度审慎的项目审查制度; 搭建高效透明的风险 控制机制；设立公平公开的信息披露制度。

\section{3、加强投资者教育，树立科学的投资理念。}

加强投资者教育，有利于投资者理性参与股权众筹投资。做好这项工作，一是突出众筹 平台的宣教功能。二是强制执行投资下单前的警示与下单后的冷却操作流程。设置下单前的 警示语和下单后冷却期。

\section{4、加强征信体系建设，规范股权众筹平台}

征信是互联网的基石，互联网金融对于投融资双方的资信状况更加依赖。股权众筹平台 对融资人的资信状况难以详细了解且调查成本大, 信息不对称极易引发道德风险。加强征信 可一方面设立专口机构负责整合分散在央行、银监会、证监会、工商、税务、法院等征信数 据, 向互联网金融平台开放。另一方面, 大力推进民营征信机构成立, 例如芝麻信用、腾讯 征信等, 对个人在互联网和现实生活中的消费行为和金融行为分析, 并制定科学的标准来评 分。股权众筹平台利用这些信息就可方便快捷且低成本地掌握融资人和领投人的信用程度。

\section{致谢}

本文为2016年西安市社科规划项目《股权型众筹驱动西安创新创业发展政策研究》(16F19) 的阶段性成果之一。

\section{References:}

[1]Jingcheng Luo.Research on the Financing of Start - up Enterprises' Stock Ownership[D].Anhui University, April,2016

[2]Guiding Opinions on Promoting the Healthy Development of Internet Finance.2015 7 .18.Chinese Government Network, http://www. gov.cn/xinwen/2015 07/18/content_2899360. htm

[3]Data Sources: sounded net http://www.mingin.com/crowdfunding/news/

[4]Haichao Zheng, Yumeng Huang、Tao Wang , Dongyu Chen.A Study on the Influencing Factors of Financing Performance of Innovative Project[J].China Soft Science .Phase one,2016 
[5]Zhichao Chen.Research on Legal System of Preventing Public Financing Risks in China[D].Anhui university of finance and economics.Nov,2015 